North America. 2nd ed. Washington. $464 \mathrm{pp}$.

7. NATIONAL GEOGRAPHIC SOCIETY. 1964. Song and garden birds of
North America. Washington. 400 pp.

8. STOKES, D.W. and L.Q. 1983. A guide to bird behaviour, Vol. 11. Little Brown and Co., Boston. 334 pp.

\title{
Thrasher
}

Mostly they skulk in thickets giving us uncertain glimpses as they perform their chores, a flash of dappled brown the rust of old oak leaves, but I saw one dancing at noon running on a hot sandy road repeatedly pecking the ground then swiping its head sideways down onto the shining sand, frenzied with ants, I guessed, as it urgently pranced erect before flying to shaded glades.
Catch them at dawn in song when they perch up high singing twice-repeated whistled phrases melodies that quiet cows or foxes, then their striped breast glows that russet tail hangs still and all the urgent woods thrill.

- Robert W. Nero, Wildlife Branch, Box 24, 1495 St. James Street, Winnipeg, Manitoba. R3H OW9

\section{SNOWY OWL CAPTURES ROCK DOVE IN MID-AIR}

ROBERT W. NERO, Wildlife Branch, Box 24, 1495 St. James Street, Winnipeg, Manitoba. R3H OW9

Snowy owls are known to take a variety of birds as prey, including pheasants, grouse, ducks, gulls, and Rock Doves, that is, common pigeons. ${ }^{1,2}$ The actual capture of a pigeon, however, is rarely witnessed. On 24 January 1994, shortly after I left the office in an industrial section of Winnipeg, I saw this happen (corner of Wellington and St. James). I was driving south at about 2:00 p.m.; just as I slowed for cars stopping at an intersection, a large dark bird flapping high overhead caught my attention. I was looking into the sun and the bird appeared black, hence my initial belief that it was a Common Raven. It appeared to be involved with three pigeons, but was it harassing them? Or was it the other way around? Just then, it reappeared from behind a building for a moment and I knew it was not a raven. I quickly turned off into a driveway, jumped out and searched the sky. It was a bright sunny day, just a little hazy, and I held my hand to shield my eyes from the sun. And, yes, "Snowy Owl!", I exclaimed. It was circling about at a height of perhaps 24 metres. As I watched, puzzled by its behaviour, it flew towards two more pigeons which were flying slowly westwards, across a strong north wind, wings upheld in the display so common to their kind. When they dropped down, the owl wheeled about and a moment later circled back towards yet another approaching pigeon, a lone bird also flying westwards. The owl gained steadily on the pigeon, overtook it and then, to my utter delight, seized it. "It caught it!", rang through my mind. 
The owl and its prey dropped down and out of my sight behind buildings, whereupon I jumped into my car and drove around frantically trying to find where the owl had come down. I wanted to determine, if possible, its age and sex. Finally, I parked the car, hurried over the top of a pile of snow and ran down a railroad track into the cold wind, searching wildly. It was a strong cold wind, the temperature, as I later learned, being $-20^{\circ} \mathrm{C}$. I couldn't find the owl, but there were a dozen large flat roofs nearby and I concluded that the owl must have landed on top of one of them, out of sight. My impression is that the owl was mostly white, perhaps an adult male or female, but viewing conditions were poor.

The more I watch Snowy Owls, the more impressed I am with their ver- satility. Usually, I just drive around in the country counting them, marvelling at their ability to perch high on top of steel hydro towers at $-30^{\circ} \mathrm{C}$ with a strong wind blowing. Thirty years ago in the Blue Jay, I described the capture of a Lesser Scaup by a Snowy Owl. ${ }^{3}$ This present observation of a Snowy Owl capturing a Rock Dove as adeptly as a Peregrine Falcon has further enhanced my image of this large raptor.

1. JOHNSGARD, P.A. 1988. North American owls. Smithsonian Institution Press, Washington, D.C. 295 pp.

2. MIKKOLA, H. 1983. OwIs of Europe. Buteo Books, Vermillion, South Dakota. $397 \mathrm{pp}$.

3. NERO, R.W. 1964. Snowy Owl captures duck. Blue Jay 22: 54-55.

\title{
JANUARY SIGHTING OF A NORTHERN SHRIKE IN REGINA
}

\author{
JEANNETTE PEPPER, 50 Sommerfeld Drive, Regina, Saskatchewan. S4V 0C7
}

During the particulary cold week of 12-19 January 1994, an especially interesting guest visited our yard in southeast Regina, Saskatchewan. Our family had been enjoying the company of redpolls, Pine Siskins, nuthatches and chickadees at our two bird feeders throughout December. On 12 January, shortly after 12:00 p.m. a Northern Shrike landed in an apple tree. It proceeded to finish eating something it had caught. Wayne (Pepper) and I were unsure if its prey was one of our regular visitors since we could not clearly identify it.
Although both the Northern and Loggerhead Shrike are grey and black birds with white breasts, our visitor had a black mask through the eyes, not an eye bar which is characteristic of the Loggerhead Shrike. ${ }^{1}$ As well, the Loggerhead Shrike only winters from the north-central United States southward. ${ }^{1}$ Since the wind chill factor was approximately 2300 at the time of the sightings, we were convinced that we were actually observing a species which is known to wander as far south as Regina in mid-winter. 